\title{
Egg and meat production performances of two varieties of the local Ardennaise poultry breed: silver black and golden black
}

\author{
N. Moula, C. Michaux, F.X. Philippe, N. Antoine-Moussiaux and P. Leroy \\ Department of Animal production, Division of Genetics, Biostatistics and Rural Economics, Faculty of Veterinary Medicine, \\ University of Liege, Liege, Belgium
}

\begin{abstract}
Summary
The Ardennaise breed is emblematic of the Belgian poultry diversity. We compared two varieties of the breed, the golden black and the silver black. The comparison encompassed: (i) the morphology of adult birds, (ii) the growth, carcass characteristics and meat quality of broilers 22 weeks old, (iii) the laying rate during 52 weeks and the egg quality. Significant differences were observed in the size of mature males and females: body weight, diameter and length of the tarsus, size of the comb and wattles. The two varieties did not differ concerning the carcass and meat quality traits. The golden black has a higher laying rate and a higher yolk / albumen ratio, but lays lighter eggs. It could be interesting to complete this study by molecular markers analysis to evaluate the degree of genetic diversity between the two varieties.
\end{abstract}

Keywords: Ardennaise breed, poultry diversity, morphology, breeding, broiler and laying performances

\begin{abstract}
Résumé
La poule Ardennaise est une race emblématique de la biodiversité avicole belge. Cette étude est consacrée à la comparaison de deux variétés de la race Ardennaise (Noire dorée et Noire Argentée). La comparaison est réalisée par le biais de trois études: (1) caractérisation morpho-biométrique des deux variétés; (2) caractérisation de la croissance et de la qualité de la carcasse et de la viande; (3) suivi du taux de ponte pendant 52 semaines et étude de la qualité des œufs à 30, 45, 60 et 75 semaines d'âge. Des différences significatives ont été enregistrées entre les deux variétés au niveau des poids corporels, du grand diamètre du tarse, de la longueur du tarse et de la taille de la crête. La variété de la poule Ardennaise n'influence significativement aucun des caractères quantitatif et qualitatif de production de viande (rendement, poids après abattage, $\mathrm{pH}$, couleur de la viande). Cependant, elle influence significativement le poids de l'œuf entier, le poids du blanc, le pourcentage du blanc, le pourcentage du jaune, le rapport jaune/blanc et le $\mathrm{pH}$ du blanc $(p<0.05)$. Il serait intéressant de compléter cette étude par une analyse moléculaire permettant de préciser le degré de similitude génétique entre les deux variétés et éventuellement avec les autres variétés de la race.
\end{abstract}

Mots-clés: race Ardennaise, diversité aviaire, morphologie, sélection, poulet de chair et performances de ponte

\section{Resumen}

La raza Ardenesa es una raza emblemática dentro de la diversidad avícola belga. Se han comparado dos variedades de la raza, la negra dorada y la negra plateada. La comparación comprendió (i) la morfología de aves adultas, (ii) el crecimiento, características de la canal y calidad de la carne de pollos broiler de 22 semanas de edad, (iii) la tasa de puesta durante 52 semanas y la calidad del huevo. Se observaron diferencias significativas en el tamaño de machos y hembras maduros: peso corporal, diámetro y longitud de los tarsos, tamaño de la cresta y de las barbillas. Las dos variedades no difirieron en lo que respecta a parámetros de la canal o de calidad de carne. La variedad negra dorada presenta una mayor tasa de puesta y un mayor ratio yema/albumen, pero pone huevos de menor peso. Podría resultar interesante completar este estudio con un análisis de marcadores moleculares para evaluar el grado de diversidad genética entre las dos variedades.

Palabras clave: raza Ardenesa, diversidad avícola, morfología, mejora, rendimientos cárnicos y de puesta

Correspondence to: Dr N. Moula and Professor P. Leroy. Moula, Department of Animal production, Division of Genetics, Biostatistics and Rural Economics, Faculty of Veterinary Medicine, University of Liege, Liege, Belgium. emails: Nassim.Moula@ulg.ac.be; pascal.leroy@ulg.ac.be

\section{Introduction}

All through the industrialization process of western countries in the nineteenth and twentieth centuries, modern poultry production has turned to a true landless, input and capital intensive production system, exclusively based on 
highly productive and specialized hybrid strains. Sustained by the rapid genetic progress allowed by the short lifecycle of the poultry as well as by the economies of scale (increasing returns), a highly concentrated economic sector has emerged, where the global production hardly relies on a few major genetic types (Lariviere and Leroy, 2008). Nowadays, a rapid demand-driven expansion of the livestock sector in developing countries is taking place (Delgado et al., 1999). In this so-called Livestock Revolution, the intensive peri-urban poultry sector did more than its fair share in the satisfaction of the rising demand for animal products in developing urban centres. However, this industrialization process of egg and chicken production constitutes a serious threat to the genetic diversity of poultry around the world. This trend could be particularly damaging to backyard small-scale poultry rearing that emerged these last few years as a powerful tool in poverty alleviation, in which the need for wide genetic resources cannot be overvalued, as a result of the wide array of environmental conditions to be considered. In developed countries also, a major evolution of consumption habits is converting the animal production sector to more qualitative concerns, for which valorization of local breeds should be of prime interest.

In Belgium, where 95 percent of local poultry breeds are greatly endangered (Larivière and Leroy, 2005), a local breed named Ardennaise is considered as promising in the context of quality terroir production (Moula et al., 2009a, 2009b), the flavour of its flesh being largely renowned. By its remarkable robustness and its resistance to humid climates, this breed has also been proposed for amelioration projects of village chicken production in Sub-Saharan Africa (Youssao et al., 2009). The Ardennaise breed is actually composed of 12 recognized varieties, of which the white one is sometimes considered as a different breed, named the Famennoise (Moula et al., 2009a, 2009b, 2009c; Moula et al., 2012). As the selection process that gave birth to those varieties has been realized on the basis of non-productive phenotypic traits (plumage and eye colour and morpho-biometric characteristics), the question of the relevance of their differentiation regarding production objectives must be considered. In this context, the present study aims at evaluation of egg and meat production abilities of the two major Ardennaise varieties, namely, the silver black feathered and the golden black feathered Ardennaise.

\section{Material and methods}

This study was implemented from January 2008 till December 2009 and involved three phases. The first phase consisted in the morpho-biometric characterization of Ardennaise individuals from both silver and golden varieties available at the Animal Production Department of the Faculty of Veterinary Medicine of the University of Liege (Belgium). In the second phase, the meat production performances were recorded through the follow-up of live weight for a growth period of 22 weeks and the assessment of meat quality at slaughter. Quantitative and qualitative egg production performances were then studied during a third phase for a 52-weeks laying period.

\section{Morpho-biometry}

Adult birds (over 10 months of age) of the silver black and the golden black varieties from breeding flocks were used for the morpho-biometric characterization. The different body measurements were recorded in accordance with the FAO recommendations (FAO, 1981), by means of a digital balance (precision $1 \mathrm{~g}$ ), an electronic sliding caliper (precision $0.01 \mathrm{~mm}$ ) and a tape measure.

The collected data were thus the sex and age of the bird, the comb's length and height, wattles height, the length and diameter of the tarsus and the beak.

\section{Growth and carcass and meat quality}

A total of 304 eggs, among which 130 of the silver black Ardennaise and 174 of the golden black Ardennaise, were incubated. All the eggs were less than 10 days old and originated from the flock of the Veterinary Faculty. The number of chicks obtained was 90 for the silver black and 124 for the golden black variety. All the chicks were vaccinated against Marek's disease at day 1.

All the chicks were floor-bred on a sawdust litter in the same ventilated building, both varieties being separated by netting. The chicks were first put under a heating lamp and the room temperature was regulated manually according to the chicks' behaviour. Continuous light program was adopted for the whole experiment period. The chicks were fed ad libitum with a starter mix until the age of 14 days (energy: $2870 \mathrm{kcal} / \mathrm{kg}$, density: $0.732 \mathrm{~kg} / \mathrm{l}$ ) and a traditional poultry mix (energy: $2950 \mathrm{kcal} / \mathrm{kg}$, density: $0.723 \mathrm{~kg} / \mathrm{l})$ from day 14 to slaughter. Between days 14 and 21, both feed types were mixed to provide an adaptation period. Both mixes contained wheat, corn, soyabean, soyabean oil, methionine, lysine, vitamins and BHT ethoxyquine anti-oxidant. Their compositions are listed in Table 1.

Each bird was identified individually, first by a numbered plastic ring at the leg then by metallic ones after week 5. Sexing was achieved visually at week 9 by comb inspection. The birds were weighed individually once a week from week 1 till week 16 with an electronic balance (accuracy $0.01 \mathrm{~g}$ ). The birds were weighed once again, at week 22 , before slaughter. An overall feed conversion index was calculated for each variety from the total feed intake and the total gain.

Mortality was recorded during the growing period.

Four birds of each sex were randomly chosen among each variety $(n=16)$ and were slaughtered at week 22 , which is the regular slaughter age for slow-growing local breeds 
Table 1. Feed mix composition for starting, growth and laying.

\begin{tabular}{lrrr}
\hline Ingredients & $\begin{array}{c}\text { Broiler } \\
\text { Starter } \\
\text { mix }\end{array}$ & $\begin{array}{c}\text { Broiler } \\
\text { mix }\end{array}$ & \multicolumn{1}{c}{$\begin{array}{c}\text { Layer } \\
\text { hens }\end{array}$} \\
\hline Soyabean oil cake & 32.00 & 30.00 & 20.00 \\
Wheat & 37.00 & 31.00 & 11.00 \\
Corn & 25.00 & 33.00 & 50.00 \\
Soyabean oil & 2.30 & 2.00 & 3.00 \\
Calcium phosphate & 1.50 & 1.80 & 1.00 \\
Minerals (vitamins, micronutrients) ${ }^{1}$ & 1.10 & 1.00 & 1.00 \\
Calcium carbonate & 1.08 & 1.20 & 7.50 \\
Methionine & 0.02 & 0.20 & 0.10 \\
Alfalfa & - & - & 2.40 \\
Beets molasse & - & - & 1.50 \\
Wheat middlings & - & - & 2.50 \\
Composition & & & \\
Metabolizable energy $(\mathrm{kcal} / \mathrm{kg})$ & 2870.00 & 2950.00 & 3060.40 \\
Fat content $(\mathrm{g} / \mathrm{kg})$ & 55.13 & 52.18 & 54.53 \\
Lysine $(\mathrm{g} / \mathrm{kg})$ & 12.45 & 8.46 & 11.28 \\
Methionine $(\mathrm{g} / \mathrm{kg})$ & 5.39 & 3.45 & 4.36 \\
Calcium $(\mathrm{g} / \mathrm{kg})$ & 9.50 & 38.00 & 10.00 \\
Phosphorus $(\mathrm{g} / \mathrm{kg})$ & 6.03 & 5.62 & 5.68 \\
Dry matter $(\mathrm{g} / \mathrm{kg})$ & 612.90 & 749.60 & 561.26 \\
Crude protein $(\mathrm{g} / \mathrm{kg})$ & 220.00 & 170.00 & 189.00 \\
\hline
\end{tabular}

${ }^{1}$ Vitamin A $13500 \mathrm{UI} / \mathrm{kg}$, vitamin D3 $3.000 \mathrm{UI} / \mathrm{kg}$, vitamin E $25 \mathrm{mg} / \mathrm{kg}$ and copper sulphate $15 \mathrm{mg} / \mathrm{kg}$.

such as the Ardennaise. The birds were deprived of feed for $15 \mathrm{~h}$ before last live weight record and slaughter. They were bled, plucked under warm water, weighed again and eviscerated. The legs were sectioned at the tibiotarsus-metatarsus joint and the head was cut at the skull-atlas joint. The warm carcass was then weighed. The dressing out percentage was then calculated as the ratio between warm carcass weight and live weight at slaughter.

The carcass was then cut and the wings, legs and drumsticks were sampled and weighed after being skinned. The left pectoral muscles (Pectoralis major and Pectoralis profondus) were sampled about $8 \mathrm{~h}$ postslaughter, weighed and packed in plastic bags for conservation at $4{ }^{\circ} \mathrm{C}$ for $24 \mathrm{~h}$. Water loss was calculated as the difference between muscles' weight at sampling and after $24 \mathrm{~h}$ of draining on absorbent paper.

pH was measured with a Portamess 751 pH-meter (Knick GmbH\&Co, Berlin, Germany) combined with a MettlerToledo electrode (LoT406-DXKS7/25; Mettler-Toledo International Inc., Urdorf, Switzerland). Meat colour of the left pectoral muscles was determined on three different parts of each sample after exposition to air, with a spectrocolourimeter Hunterlab Lab-Scan II (Hunter Associates Laboratory, Reston, USA). Colour was expressed in CIE units: $L^{*} a^{*} b^{*}$ with $L^{*}$ being a value indicating the darkness (lightness), high values of $\mathrm{a}^{*}$ indicating an intense red colour of meat (redness) and high values of $b^{*}$ indicating an intense yellow colour of the meat (yellowness).

\section{Egg production and quality}

Egg laying rate was assessed in 40 silver black and 30 golden black. The hens were first housed under natural light conditions. At week 24, the hens began to produce small eggs and were transferred at week 28 in a building under artificial lighting where a $16 \mathrm{~h}$ light $/ 8 \mathrm{~h}$ dark programme was applied. The hens were fed with a mix for layers, containing $10 \mathrm{~g} / \mathrm{kg}$ calcium (see Table 1 for composition). Laying was followed-up for 52 weeks. The eggs were collected every day and conserved at $6{ }^{\circ} \mathrm{C}$ except abnormal eggs (cracked and broken) which were eliminated. Quality analysis was implemented the day after egg collection and conducted at different hens' ages: 30, 45, 60 and 80 weeks. Total weight was measured (electronic balance, accuracy $0.01 \mathrm{~g}$ ) and average egg weight was obtained by dividing total eggs weight by eggs number. Then, their length and width were measured by means of an electronic sliding caliper (precision $0.01 \mathrm{~mm}$ ), so that an egg shape index could be calculated as the ratio between length and width multiplied by 100 (Monira, Salahuddin and Miah, 2003; Parmar et al., 2006). The yolks were carefully separated from the albumen. The shells including the membranes and yolks were weighed separately (accuracy of $0.01 \mathrm{~g}$ ). Albumen weight was determined by subtracting yolk and shell weights from the total egg weight. The shell thickness was measured at three different random points in the equatorial shell zone using an electronic micrometer (precision $0.01 \mathrm{~mm}$ ) and average calculated. Tyler and Geake (1964) indeed reported the eggshell thickness to be slightly thinner but more stable in the equatorial shell zone compared with the other shell zones. Yolk and albumen $\mathrm{pH}$ was then measured with a pH-meter (ORION, model 290A, 1990 Orion Research Inc. Boston, MA 02129, USA).

\section{Statistical analyses}

The analysis of data was conducted by using the SAS package (procedure GLM, SAS, 2001) and least square means (LSM) and standard errors were calculated, allowing ranking of variety and sexes according to Duncan's procedure.

The following models were used.

$$
Y_{i j k}=\mu+A_{i}+B_{j}+(A B)_{i j}+e_{i j k}
$$

where $Y_{i j k}$ are the mature body weight and measurements and meat quality traits in 22-week-old chicks, $\mu$ is the overall mean, $A_{i}$ is the fixed effect of the $i$ th variety (golden black and silver black variety), $B_{j}$ is the fixed effect of the $j$ th gender (male, female) and $e_{i j k}$ is the random residual effect.

$$
\begin{aligned}
Y_{i j k l}= & \mu+A_{i}+B_{j}+C_{k}+(A B)_{i j}+(A C)_{i k} \\
& +(B C)_{j k}+(A B C)_{i j k}+e_{i j k l}
\end{aligned}
$$

where $Y_{i j k l}$ is the body weight, $\mu$ is the overall mean; $A_{i}$ is 
the fixed effect of the $i$ th variety (golden black and silver black variety), $B_{j}$ is the fixed effect of the $j$ th gender (male, female), $C_{k}$ is the fixed effect of the $k$ th age (1 to 22 weeks), and $e_{i j k l}$ is the random residual effect.

$$
Y_{i j k}=\mu+A_{i}+B_{j}+(A B)_{i j}+e_{i j k}
$$

where $Y_{i j k}$ is the egg quality traits, $\mu$ is the overall mean, $A_{i}$ is the fixed effect of the $i$ th variety (golden black and silver black variety), $B_{j}$ is the fixed effect of the age $(30,45,60$ and 80 weeks) and $e_{i j k}$ is the random residual effect.

The Gompertz equation was used to model the growth of the chickens (Porter et al., 2010). This equation has the form: $Y=\alpha e^{-\beta e^{-\gamma t}}$

where $Y$ is the weight of the chicken in grams, $\alpha$ is the asymptotic weight, $\beta$ is constant, $\gamma$ is growth speed factor (maturation factor), and $t$ is the age in days.

The growth curve parameters of the Gompertz equation were estimated (proc NLIN, SAS, 2001). The age at inflexion when the growth rate is maximum was calculated using the following formula (Porter et al., 2010): $t_{\mathrm{i}}=(1 / \gamma) \times$ $\ln |\beta|$

To compare the egg-laying rate, hatching rate and mortality rate between the silver black and the golden black varieties, the Chi squared test was used.

\section{Results}

\section{Morpho-biometric characteristics}

The least squares means of the live weight and body measurements of mature animals are given in table 2 along with the significance of the fixed effects of sex and variety.

The sex effect is highly significant $(P<0.001)$ on all studied traits. The effects of variety and interaction variety $\times$ sex were significant $(P<0.05)$ on body weight, large diameter and length of the tarsus and on the comb length. The males of the golden black variety were significantly $(P<0.05)$ heavier $(2674 \mathrm{~g})$ than the males of the silver golden black variety (2 $290 \mathrm{~g}$ ) but the live weight was not significantly different between the hens of the two varieties.

Golden black males had body measurements (length of the tarsal, the length and height of the comb and the length of the wattles) greater $(P<0.05)$ than the silvery black variety. In females, there was no significant difference in comb height and wattles length between the two varieties (Table 2).

\section{Growth}

Figure 1 shows the live weight growth of the birds from 1 day old (36 g for all sex and varieties) up to 22 weeks

Table 2. Body weight $(\mathrm{g})$ and measurements $(\mathrm{mm})$ of adult Ardennaise chicken according to variety $(\mathrm{V})$ and sex (S), least squares means and standard error and significance level of the effects of variety, sex and their interaction $(\mathrm{V} \times \mathrm{S})$.

\begin{tabular}{|c|c|c|c|c|c|c|c|c|}
\hline & \multicolumn{2}{|c|}{ Golden black } & \multicolumn{2}{|c|}{ Silver black } & \multicolumn{3}{|c|}{ Level of significance } & \multirow[t]{2}{*}{$R^{2}$} \\
\hline & $n$ & $\mathbf{L S M} \pm \mathbf{S E}$ & $n$ & $\mathbf{L S M} \pm \mathbf{S E}$ & $\mathbf{V}$ & $\mathbf{S}$ & $\mathbf{V} \times \mathbf{S}$ & \\
\hline Body weight (g) & & & & & $* *$ & $* * *$ & $* *$ & 0.28 \\
\hline Male & 10 & $2674 \pm 95^{\mathrm{a}}$ & 26 & $2290 \pm 59^{b}$ & & & & \\
\hline Female & 52 & $1956 \pm 42$ & 97 & $1972 \pm 30$ & & & & \\
\hline Small diameter of tarsus & & & & & NS & $* * *$ & NS & 0.37 \\
\hline Male & 10 & $11.98 \pm 0.30$ & 26 & $11.41 \pm 0.19$ & & & & \\
\hline Female & 52 & $9.64 \pm 0.13$ & 97 & $9.79 \pm 0.10$ & & & & \\
\hline Large diameter of tarsus & & & & & $*$ & $* * *$ & $*$ & 0.18 \\
\hline Male & 10 & $15.62 \pm 0.43^{\mathrm{a}}$ & 26 & $14.43 \pm 0.27^{\mathrm{b}}$ & & & & \\
\hline Female & 52 & $13.24 \pm 0.19$ & 97 & $13.28 \pm 0.14$ & & & & \\
\hline Length of tarsus & & & & & $*$ & $* * *$ & $* *$ & 0.21 \\
\hline Male & 10 & $94.53 \pm 2.60^{\mathrm{a}}$ & 26 & $85.90 \pm 1.61^{\mathrm{b}}$ & & & & \\
\hline Female & 52 & $77.88 \pm 1.14$ & 97 & $79.53 \pm 0.83$ & & & & \\
\hline Beak length & & & & & NS & $* * *$ & NS & 0.22 \\
\hline Male & 10 & $36.84 \pm 0.87$ & 26 & $35.35 \pm 0.54$ & & & & \\
\hline Female & 52 & $32.22 \pm 0.38$ & 97 & $32.17 \pm 0.28$ & & & & \\
\hline Comb length & & & & & $*$ & $* * *$ & $*$ & 0.34 \\
\hline Male & 10 & $122.39 \pm 8.41^{\mathrm{a}}$ & 26 & $96.02 \pm 5.21^{\mathrm{b}}$ & & & & \\
\hline Female & 52 & $58.73 \pm 3.69$ & 97 & $57.22 \pm 2.70$ & & & & \\
\hline Comb height & & & & & NS & $* * *$ & NS & 0.55 \\
\hline Male & 10 & $74.78 \pm 5.00$ & 26 & $63.69 \pm 3.10$ & & & & \\
\hline Female & 52 & $22.41 \pm 2.19$ & 97 & $23.57 \pm 1.61$ & & & & \\
\hline Wattles length & & & & & NS & $* * *$ & $*$ & 0.56 \\
\hline Male & 10 & $61.01 \pm 3.93^{\mathrm{a}}$ & 26 & $50.11 \pm 2.44^{\mathrm{b}}$ & & & & \\
\hline Female & 52 & $16.95 \pm 1.72$ & 97 & $19.26 \pm 1.26$ & & & & \\
\hline
\end{tabular}

$* * * P<0.001 ; * * P<0.01 ; * P<0.05$; NS: $P>0.05$. LSM \pm SE: Least squares means \pm SE; a, b: different superscripts indicate significant differences $(P<0.05)$. 


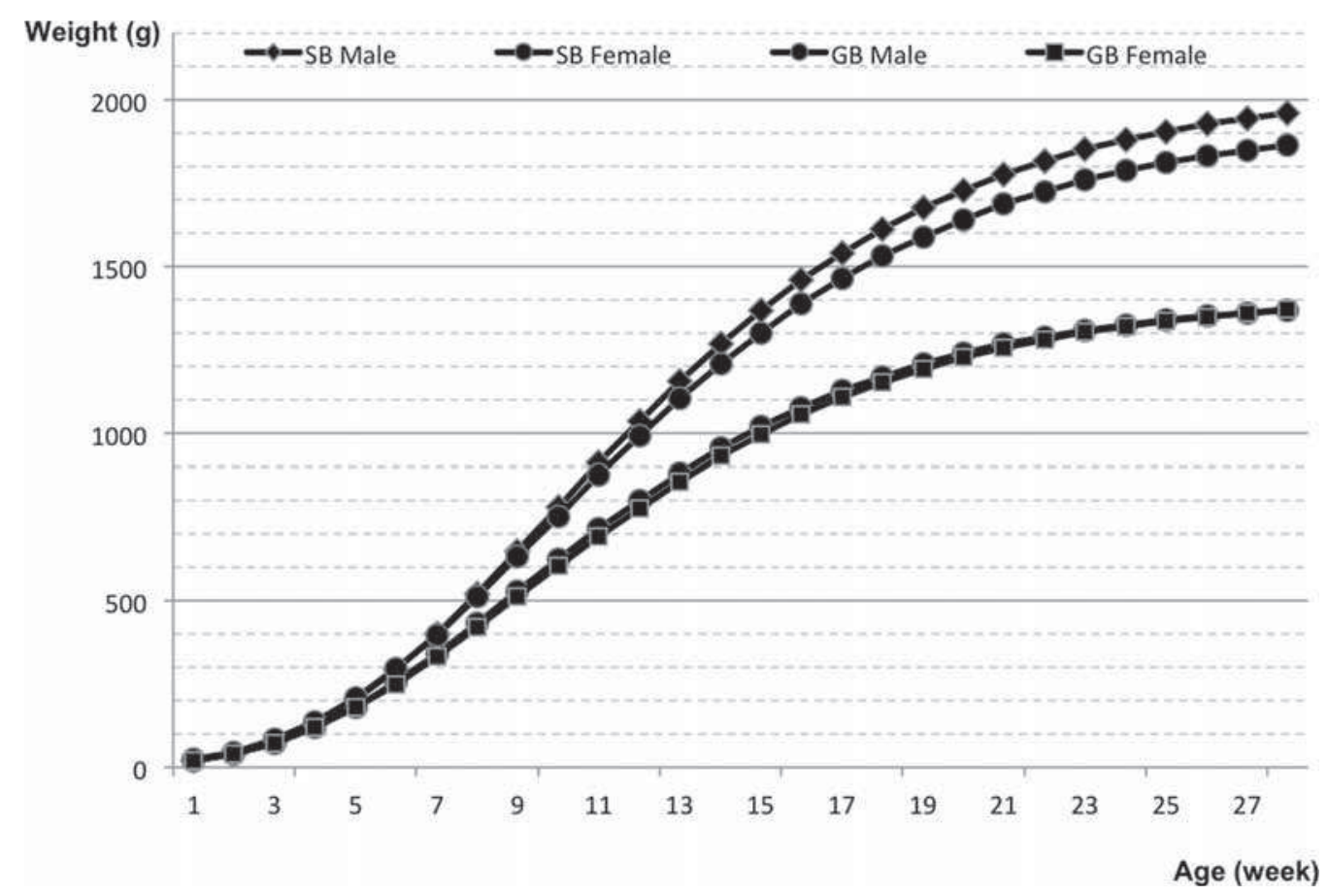

Figure 1. Gompertz growth curve parameters of Ardennaise broilers by varieties (SB, Silver black; GB, Golden black) and sex.

of age. Mean weight at 22 weeks of age was 1550 and 1 $513 \mathrm{~g}$ in golden and silver varieties, respectively. The body weight was significantly $(P<0.01)$ influenced by the fixed effects of the variety, the sex, the age and the interaction between sex and age (Table 3).
The parameters of the Gompertz curve, the average daily gain (ADG) and the feed conversion ratio (FCR) of the two Ardennaise varieties and sexes are shown in Table 4. Asymptotic weights were 2042 and $1946 \mathrm{~g}$ in males and 1411 and $1420 \mathrm{~g}$ in females for the silver

Table 3. Body weight of Ardennaise broilers by variety (V), sex (S) and age (A). LSM \pm SE and significance level of the effects of variety, sex and age and their interactions.

\begin{tabular}{|c|c|c|c|c|c|c|c|c|c|c|c|c|c|}
\hline & \multicolumn{3}{|c|}{ Golden black } & \multicolumn{3}{|c|}{ Silver black } & \multicolumn{7}{|c|}{ Level of significance } \\
\hline & Male (41) & Female (39) & Total (90) & Male (55) & Female (69) & Total (124) & V & $\mathbf{S}$ & A & $\mathbf{V} \times \mathbf{S}$ & $\mathbf{V} \times \mathbf{A}$ & $\mathbf{S} \times \mathbf{A}$ & $\mathbf{V} \times \mathbf{A} \times \mathbf{S}$ \\
\hline Day 1 & 35.8 & 35.6 & 35.6 & 36.5 & 35.4 & 35.9 & ** & $* * *$ & $* * *$ & NS & NS & $* * *$ & NS \\
\hline Week 8 & 609 & 501 & 555 & 618 & 494 & 556 & & & & & & & \\
\hline Week 12 & 1139 & 870 & 1007 & 1111 & 848 & 977 & & & & & & & \\
\hline Week 16 & 1518 & 1147 & 1338 & 1446 & 1126 & 1282 & & & & & & & \\
\hline Week 22 & 1814 & 1258 & 1550 & 1752 & 1266 & 1513 & & & & & & & \\
\hline
\end{tabular}

(), number of specimens; V, varieties; $\mathrm{S}$, sex; A, age. ${ }^{* * *} P<0.001 ;{ }^{* *} P<0.01 ;{ }^{*} P<0.05$; NS, $P>0.05$.

Table 4. Gompertz growth curve parameters, average daily gain (ADG) and feed conversion ratio (FCR) of Ardennaise broilers by variety and sex.

\begin{tabular}{|c|c|c|c|c|c|c|c|c|c|c|c|c|c|c|}
\hline \multirow[t]{2}{*}{ Variety } & \multirow[t]{2}{*}{ Sex } & \multirow[t]{2}{*}{$N$} & \multicolumn{4}{|c|}{$\begin{array}{l}\text { Parameters of the Gompertz } \\
\text { growth curve }\end{array}$} & \multicolumn{4}{|c|}{ ADG by age (g/j) } & \multicolumn{4}{|c|}{ Global FCR by age (g/g) } \\
\hline & & & $\alpha(\mathrm{g})$ & $\beta$ & $\gamma\left(\mathbf{j}^{-1}\right)$ & $t(j)$ & $\begin{array}{c}0-8 \\
\text { weeks }\end{array}$ & $\begin{array}{c}0-12 \\
\text { weeks }\end{array}$ & $\begin{array}{c}0-16 \\
\text { weeks }\end{array}$ & $\begin{array}{c}0-22 \\
\text { weeks }\end{array}$ & $\begin{array}{c}0-8 \\
\text { weeks }\end{array}$ & $\begin{array}{c}0-12 \\
\text { weeks }\end{array}$ & $\begin{array}{c}0-16 \\
\text { weeks }\end{array}$ & $\begin{array}{c}0-22 \\
\text { weeks }\end{array}$ \\
\hline \multirow[t]{3}{*}{ Silver black } & Males & 41 & 2042.3 & 4.66 & 0.1725 & 62.45 & 10.23 & 13.13 & 13.23 & 11.55 & & & & \\
\hline & Females & 39 & 1410.6 & 4.279 & 0.1841 & 55.27 & 8.31 & 9.93 & 9.92 & 7.94 & & & & \\
\hline & Total & 90 & 1760.3 & 4.48 & 0.1752 & 59.65 & 9.27 & 11.56 & 11.63 & 9.83 & 3.03 & 4.01 & 4.49 & 6.71 \\
\hline \multirow[t]{3}{*}{ Golden black } & Males & 55 & 1945.7 & 4.454 & 0.1718 & 60.86 & 10.40 & 12.80 & 12.59 & 11.14 & & & & \\
\hline & Females & 69 & 1419.9 & 4.203 & 0.1766 & 56.91 & 8.19 & 9.67 & 9.74 & 7.99 & & & & \\
\hline & Total & 124 & 1691.3 & 4.308 & 0.1714 & 59.92 & 9.28 & 11.20 & 11.12 & 9.59 & 2.98 & 3.99 & 4.60 & 6.19 \\
\hline
\end{tabular}

$\alpha$ is the asymptotic weight; $\beta$ is constant; $\gamma$ is the growth rate parameter (maturing factor); $t$ is age in days. 
black and the golden black, respectively. The age of inflexion was near 60 days for the silver and golden varieties.
The overall FCR was similar for the two varieties during the first 16 weeks and slightly higher in silver black thereafter. The birds of the silver black and golden black variety

Table 5. Carcass and meat quality traits of Ardennaise broilers by variety and sex. LSM $\pm \mathrm{SE}$ and significance level of the effects of sex.

\begin{tabular}{|c|c|c|c|c|c|}
\hline & \multicolumn{2}{|c|}{ Silver black variety } & \multicolumn{2}{|c|}{ Golden black variety } & \multirow{2}{*}{$\begin{array}{c}\text { Level of significance } \\
\text { Sex }\end{array}$} \\
\hline & $n$ & $\mathbf{L S M} \pm \mathbf{S E}$ & $n$ & $\mathbf{L S M} \pm \mathbf{S E}$ & \\
\hline Slaughter body weight (g) & & & & & $* * *$ \\
\hline Male & 4 & $1856 \pm 28$ & 5 & $1803 \pm 25$ & \\
\hline Female & 4 & $1441 \pm 28$ & 5 & $1399 \pm 25$ & \\
\hline Carcass weight (g) & & & & & $* * *$ \\
\hline Male & 4 & $1249 \pm 27$ & 5 & $1237 \pm 24$ & \\
\hline Female & 4 & $931 \pm 27$ & 5 & $913 \pm 24$ & \\
\hline Yield (\%) & & & & & $* *$ \\
\hline Male & 4 & $67.30 \pm 0.95$ & 5 & $68.56 \pm 0.85$ & \\
\hline Female & 4 & $64.59 \pm 0.95$ & 5 & $65.29 \pm 0.85$ & \\
\hline Head weight (g) & & & & & $* * *$ \\
\hline Male & 4 & $62.38 \pm 1.06$ & 5 & $58.82 \pm 0.95$ & \\
\hline Female & 4 & $35.33 \pm 1.06$ & 5 & $35.76 \pm 0.95$ & \\
\hline Legs weight (g) & & & & & ** \\
\hline Male & 4 & $67.05 \pm 1.00$ & 5 & $69.41 \pm 0.89$ & \\
\hline Female & 4 & $38.60 \pm 1.00$ & 5 & $36.91 \pm 0.89$ & \\
\hline Abdominal fat weight (g) & & & & & $* *$ \\
\hline Male & 4 & $63.51 \pm 2.30$ & 5 & $69.59 \pm 2.06$ & \\
\hline Female & 4 & $76.16 \pm 2.30$ & 5 & $72.90 \pm 2.06$ & \\
\hline Drumsticks + thighs weight (g) & & & & & $* * *$ \\
\hline Male & 4 & $418.14 \pm 16.82$ & 5 & $417.86 \pm 15.04$ & \\
\hline Female & 4 & $329.70 \pm 30.55$ & 5 & $293.00 \pm 15.04$ & \\
\hline Drumsticks and thighs weight without skin (g) & & & & & $* * *$ \\
\hline Male & 4 & $392.85 \pm 15.50$ & 5 & $385.73 \pm 13.86$ & \\
\hline Female & 4 & $305.54 \pm 15.50$ & 5 & $272.01 \pm 13.86$ & \\
\hline Wings weight (g) & & & & & $* * *$ \\
\hline Male & 4 & $169.33 \pm 1.38$ & 5 & $165.98 \pm 1.24$ & \\
\hline Female & 4 & $129.88 \pm 1.38$ & 5 & $128.29 \pm 1.24$ & \\
\hline Pectoral muscle weight (g) & & & & & ** \\
\hline Male & 4 & $282.21 \pm 10.83$ & 5 & $287.30 \pm 9.69$ & \\
\hline Female & 4 & $246.41 \pm 10.83$ & 5 & $239.30 \pm 9.69$ & \\
\hline Drip loss after 1 day of storage (\%) & & & & & NS \\
\hline Male & 4 & $0.55 \pm 0.13$ & 5 & $0.80 \pm 0.12$ & \\
\hline Female & 4 & $0.68 \pm 0.13$ & 5 & $0.62 \pm 0.12$ & \\
\hline Drip loss after 3 days of storage (\%) & & & & & NS \\
\hline Male & 4 & $3.03 \pm 0.27$ & 5 & $2.98 \pm 0.24$ & \\
\hline Female & 4 & $2.69 \pm 0.27$ & 5 & $2.41 \pm 0.24$ & \\
\hline Drip loss after cooking (\%) & & & & & NS \\
\hline Male & 4 & $18.52 \pm 1.43$ & 5 & $20.72 \pm 1.43$ & \\
\hline Female & 4 & $22.60 \pm 1.43$ & 5 & $20.71 \pm 1.16$ & \\
\hline pH ultimate & & & & & NS \\
\hline Male & 4 & $5.68 \pm 0.04$ & 5 & $5.73 \pm 0.04$ & \\
\hline Female & 4 & $5.70 \pm 0.04$ & 5 & $5.67 \pm 0.04$ & \\
\hline Temperature $\left({ }^{\circ} \mathrm{C}\right)$ & & & & & NS \\
\hline Male & 4 & $17.67 \pm 1.69$ & 5 & $16.84 \pm 1.51$ & \\
\hline Female & 4 & $15.80 \pm 1.69$ & 5 & $19.16 \pm 1.51$ & \\
\hline $\mathbf{b}^{*}$ & & & & & NS \\
\hline Male & 4 & $12.41 \pm 1.53$ & 5 & $12.66 \pm 1.53$ & \\
\hline Female & 4 & $13.19 \pm 1.53$ & 5 & $13.60 \pm 1.25$ & \\
\hline$a^{*}$ & & & & & NS \\
\hline Male & 4 & $2.88 \pm 0.45$ & 5 & $3.43 \pm 0.45$ & \\
\hline Female & 4 & $3.02 \pm 0.45$ & 5 & $2.27 \pm 0.37$ & \\
\hline $\mathbf{L}^{*}$ & & & & & NS \\
\hline Male & 4 & $52.46 \pm 1.33$ & 5 & $53.13 \pm 1.19$ & \\
\hline Female & 4 & $48.35 \pm 1.33$ & 5 & $52.03 \pm 1.19$ & \\
\hline
\end{tabular}

${ }^{* * *} P<0.001 ; * * P<0.01 ; * P<0.05$; NS: $P>0.05$. LSM \pm SE: Least squares means \pm SE; $a, b$ : different superscripts indicate significant differences $(P<0.05)$.

Note: The variety $\times$ sex interaction had no significant effect on any trait. 


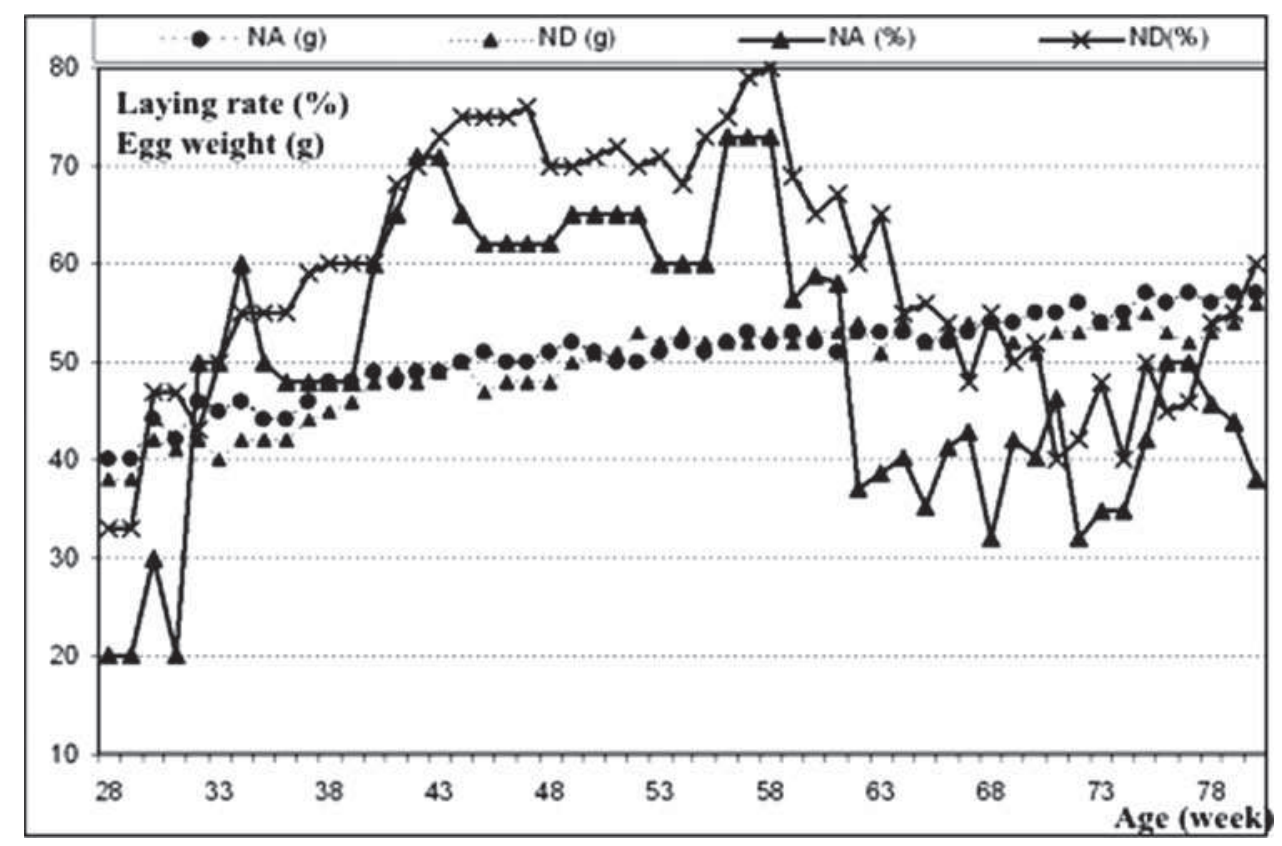

Figure 2. Evolution of laying rate (\%) and egg weight (g) during the 80 weeks laying period of the Ardennaise breed by variety (NA: Silver black; ND: Golden black).

had cumulative FCR of 3.03 and 2.98 at 8 weeks of age, 4.01 and 3.99 at 12 weeks of age, 4.49 and 4.60 at 16 weeks of age and 6.71 and 6.19 at the end of the rearing.

\section{Reproductive traits}

The hatching rate is not significantly different between the silvery black variety (69.2 percent) and the golden black variety (71.3 percent).

The mortality at 22 weeks of age, was similar $\left(\chi^{2}=0.094\right.$, $P=0.7$ ) for the two varieties and reached 6.92 and 6.32 percent for the silver black and the golden black, respectively.

\section{Carcass characteristics and meat quality}

Carcass characteristics and meat quality of the broilers at 22 weeks of age were compared for sex, variety and two factors interaction in Table 5.

The variety and the interaction of variety $\times$ sex had no significant effect on these various traits. The male showed significantly higher weights for the body, head, legs, wings, drumsticks and thighs $(P<0.01)$.

None of the various traits of meat quality were affected by any of the three factors studied.

\section{Egg production}

From the age of 28 weeks up to 80 weeks, the laying rate varied between 20 and 78 percent for the silver black and between 33 and 80 percent for the golden black (Figure 2). Over the whole laying period, the laying rate was not different between the two varieties $\left(\chi^{2}=0.57, P=0.32\right)$ neither at 30, 45, 60 and 80 weeks. The golden black produced on average 199 eggs per year and the silver black 183 eggs per year. The changes in egg weight during laying period are shown in Figure 2. The mean of the egg weight during the production period was 54.4 and $49.6 \mathrm{~g}$ for the silver black and the golden black, respectively.

\section{Egg quality}

Table 6 shows the mean values of the various traits of egg quality per variety and indicates the significance of the effects of variety, age and interaction variety $\times$ age. Only the variety has an effect $(P<0.05)$ on the egg and the albumen weights, the albumen percentage, the yolk/albumen ratio and the albumen $\mathrm{pH}$. Age influenced $(P<0.05)$ all traits related to egg quality. The weight of egg, albumen, yolk and shell and the yolk percentage increased with age. The interaction between variety and age was significant $(P<0.05)$ for the egg and yolk weights and the albumen $\mathrm{pH}$.

The two Ardennaises varieties had significant differences in the egg weight at 30 and 45 weeks of age, albumen weight at 30, 45 and 80 weeks, yolk weight at 45 and 60 weeks, albumen percentage at 60 weeks, ratio yolk/ albumen at 60 weeks, egg shape at 60 weeks and the albumen $\mathrm{pH}$ at 30 weeks.

\section{Discussion}

\section{Morpho-biometric characterization}

The first visible difference between silver black and golden black is the colour of the plumage. The colour of the hackle is easily observable, white (silver) in the silver variety and red (gold) in the golden black variety. 
Table 6. Egg quality of Ardennaise hens by variety and age. LSM \pm SE and significance level of the effects of variety, age and interaction.

\begin{tabular}{|c|c|c|c|c|c|c|c|c|}
\hline & \multicolumn{2}{|c|}{ Silver black varieties } & \multicolumn{2}{|c|}{ Golden black varieties } & \multicolumn{3}{|c|}{ Level of significance } & \multirow[t]{2}{*}{$R^{2}(\%)$} \\
\hline & $n$ & $\mathbf{L S M} \pm \mathbf{S E}$ & $n$ & $\mathbf{L S M} \pm \mathbf{S E}$ & Variety & Age & Variety $\times$ age & \\
\hline Egg weight (g) & & & & & $* * *$ & $* * *$ & ** & 85.11 \\
\hline At 30 weeks of age & 10 & $45.28 \pm 0.60^{\mathrm{a}}$ & 15 & $41.93 \pm 0.49^{b}$ & & & & \\
\hline At 45 weeks of age & 20 & $51.34 \pm 0.42^{\mathrm{a}}$ & 30 & $48.04 \pm 0.35^{\mathrm{b}}$ & & & & \\
\hline At 60 weeks of age & 15 & $53.06 \pm 0.49$ & 25 & $53.16 \pm 0.38$ & & & & \\
\hline At 75 weeks of age & 10 & $57.24 \pm 0.60$ & 15 & $55.89 \pm 0.49$ & & & & \\
\hline Albumen weight (g) & & & & & $* * *$ & $* * *$ & NS & 69.46 \\
\hline At 30 weeks of age & 10 & $26.65 \pm 0.48^{\mathrm{a}}$ & 15 & $24.19 \pm 0.39^{b}$ & & & & \\
\hline At 45 weeks of age & 20 & $29.67 \pm 0.34^{\mathrm{a}}$ & 30 & $27.88 \pm 0.28^{b}$ & & & & \\
\hline At 60 weeks of age & 15 & $30.49 \pm 0.39$ & 25 & $29.53 \pm 0.30$ & & & & \\
\hline At 75 weeks of age & 10 & $32.61 \pm 0.48^{\mathrm{a}}$ & 15 & $31.28 \pm 0.39^{\mathrm{b}}$ & & & & \\
\hline Yolk weight (g) & & & & & NS & $* * *$ & $* *$ & 68.80 \\
\hline At 30 weeks of age & 10 & $13.24 \pm 0.42$ & 15 & $12.57 \pm 0.34$ & & & & \\
\hline At 45 weeks of age & 20 & $15.72 \pm 0.30^{\mathrm{a}}$ & 30 & $14.50 \pm 0.24^{\mathrm{b}}$ & & & & \\
\hline At 60 weeks of age & 15 & $16.34 \pm 0.34^{\mathrm{a}}$ & 25 & $17.45 \pm 0.26^{\mathrm{b}}$ & & & & \\
\hline At 75 weeks of age & 10 & $18.35 \pm 0.42$ & 15 & $18.36 \pm 0.34$ & & & & \\
\hline Eggshell weight (g) & & & & & NS & $* * *$ & NS & 28.35 \\
\hline At 30 weeks of age & 10 & $5.39 \pm 0.19$ & 15 & $5.17 \pm 0.16$ & & & & \\
\hline At 45 weeks of age & 20 & $5.96 \pm 0.14$ & 30 & $5.67 \pm 0.11$ & & & & \\
\hline At 60 weeks of age & 15 & $6.23 \pm 0.16$ & 25 & $6.18 \pm 0.12$ & & & & \\
\hline At 75 weeks of age & 10 & $6.29 \pm 0.19$ & 15 & $6.24 \pm 0.16$ & & & & \\
\hline Albumen (\%) & & & & & * & ** & NS & 18.2 \\
\hline At 30 weeks of age & 10 & $58.85 \pm 0.73$ & 15 & $57.73 \pm 0.59$ & & & & \\
\hline At 45 weeks of age & 20 & $57.77 \pm 0.51$ & 30 & $58.08 \pm 0.42$ & & & & \\
\hline At 60 weeks of age & 15 & $57.46 \pm 0.59^{\mathrm{a}}$ & 25 & $55.55 \pm 0.46^{\mathrm{b}}$ & & & & \\
\hline At 75 weeks of age & 10 & $56.94 \pm 0.73$ & 15 & $55.98 \pm 0.59$ & & & & \\
\hline Yolk $(\%)$ & & & & & NS & $* * *$ & NS & 25.76 \\
\hline At 30 weeks of age & 10 & $29.23 \pm 0.69$ & 15 & $29.94 \pm 0.56$ & & & & \\
\hline At 45 weeks of age & 20 & $30.63 \pm 0.49$ & 30 & $30.12 \pm 0.40$ & & & & \\
\hline At 60 weeks of age & 15 & $30.80 \pm 0.56^{\mathrm{a}}$ & 25 & $32.83 \pm 0.44^{\mathrm{b}}$ & & & & \\
\hline At 75 weeks of age & 10 & $32.05 \pm 0.69$ & 15 & $32.85 \pm 0.56$ & & & & \\
\hline Eggshell (\%) & & & & & NS & * & NS & 9.10 \\
\hline At 30 weeks of age & 10 & $11.91 \pm 0.35$ & 15 & $12.33 \pm 0.28$ & & & & \\
\hline At 45 weeks of age & 20 & $11.61 \pm 0.25$ & 30 & $11.79 \pm 0.20$ & & & & \\
\hline At 60 weeks of age & 15 & $11.74 \pm 0.28$ & 25 & $11.63 \pm 0.22$ & & & & \\
\hline At 75 weeks of age & 10 & $11.00 \pm 0.35$ & 15 & $11.17 \pm 0.28$ & & & & \\
\hline Yolk/albumen ratio $\left(\times 10^{-2}\right)$ & & & & & * & $* * *$ & NS & 23.65 \\
\hline At 30 weeks of age & 10 & $49.72 \pm 1.90$ & 15 & $52.03 \pm 1.55$ & & & & \\
\hline At 45 weeks of age & 20 & $53.18 \pm 1.34$ & 30 & $52.12 \pm 1.10$ & & & & \\
\hline At 60 weeks of age & 15 & $53.80 \pm 1.54^{\mathrm{a}}$ & 25 & $59.49 \pm 1.20^{\mathrm{b}}$ & & & & \\
\hline At 75 weeks of age & 10 & $56.38 \pm 1.90$ & 15 & $58.85 \pm 1.54$ & & & & \\
\hline Eggshell thickness $\left(10^{-2} \mathrm{~mm}\right)$ & & & & & NS & * & NS & 8.29 \\
\hline At 30 weeks of age & 10 & $33.08 \pm 0.87$ & 15 & $32.59 \pm 0.71$ & & & & \\
\hline At 45 weeks of age & 20 & $31.88 \pm 0.62$ & 30 & $31.40 \pm 0.50$ & & & & \\
\hline At 60 weeks of age & 15 & $31.18 \pm 0.87$ & 25 & $30.90 \pm 0.71$ & & & & \\
\hline At 75 weeks of age & 10 & $30.65 \pm 0.72$ & 15 & $30.84 \pm 0.55$ & & & & \\
\hline Egg shape index & & & & & NS & ** & NS & 15.92 \\
\hline At 30 weeks of age & 10 & $74.93 \pm 0.88$ & 15 & $74.45 \pm 0.72$ & & & & \\
\hline At 45 weeks of age & 20 & $75.53 \pm 0.62$ & 30 & $75.28 \pm 0.51$ & & & & \\
\hline At 60 weeks of age & 15 & $77.67 \pm 0.72^{\mathrm{a}}$ & 25 & $75.12 \pm 0.56^{\mathrm{b}}$ & & & & \\
\hline At 75 weeks of age & 10 & $77.39 \pm 0.88$ & 15 & $77.78 \pm 0.72$ & & & & \\
\hline Albumen pH & & & & & $* *$ & $* * *$ & $* *$ & 43.70 \\
\hline At 30 weeks of age & 10 & $8.62 \pm 0.27^{\mathrm{a}}$ & 15 & $8.79 \pm 0.02^{b}$ & & & & \\
\hline At 45 weeks of age & 20 & $8.88 \pm 0.02$ & 30 & $8.88 \pm 0.01$ & & & & \\
\hline At 60 weeks of age & 15 & $8.91 \pm 0.02$ & 25 & $8.90 \pm 0.02$ & & & & \\
\hline At 75 weeks of age & 10 & $8.85 \pm 0.03$ & 15 & $8.89 \pm 0.02$ & & & & \\
\hline Yolk pH & & & & & NS & * & NS & 7.29 \\
\hline At 30 weeks of age & 10 & $6.08 \pm 0.05$ & 15 & $6.13 \pm 0.04$ & & & & \\
\hline At 45 weeks of age & 20 & $6.22 \pm 0.04$ & 30 & $6.21 \pm 0.03$ & & & & \\
\hline At 60 weeks of age & 15 & $6.21 \pm 0.04$ & 25 & $6.20 \pm 0.03$ & & & & \\
\hline At 75 weeks of age & 10 & $6.25 \pm 0.05$ & 15 & $6.23 \pm 0.04$ & & & & \\
\hline
\end{tabular}

${ }^{* * *} P<0.001 ;{ }^{*} P<0.01 ; * P<0.05 ; \mathrm{NS}: P>0.05$. LSM \pm SE: Least square means $\pm \mathrm{SE} ; \mathrm{a}$, b: different superscripts indicate significant differences $(P<0.05)$. 
The golden black cocks are significantly bigger than the silver black cocks, but the golden black hens tended to be smaller (1956 versus $1972 \mathrm{~g}$ ), increasing the sexual dimorphism in the golden black. Nevertheless, our results for mature body weight (2 $674 \mathrm{~g}$ and $1956 \mathrm{~g}$ and $2290 \mathrm{~g}$ and $1972 \mathrm{~g}$, for male and female of the golden and silver varieties, respectively) are well above those reported at the beginning of the last century by Carpiaux (1921) and Voitellier (1925) which barely exceeded 2 and $1.5 \mathrm{~kg}$ for male and female, respectively. However, these weights are close to those reported by N'Dri (2006) for the Gauloise breed (2.5 kg for rooster and 1.5-2.0 kg for hen).

\section{Growth}

The silver black and golden black Ardennaise performed similar weights at hatching (35.84 versus $36.53 \mathrm{~g}$ for males and 35.56 versus $35.42 \mathrm{~g}$ for females) and at 22 weeks (1 814 versus $1752 \mathrm{~g}$ for males and 1258 versus $1266 \mathrm{~g}$ for females).

At 12 weeks of age, the average weight was 1139 and 1 $111 \mathrm{~g}$ in males and 870 and $848 \mathrm{~g}$ in females, for the golden black and silver black, respectively, lower than the weight at 12 weeks of the white Ardennaise variety, 2000 and $1500 \mathrm{~g}$ in males and females, respectively (Moula et al., 2009a).

The ADG is also always higher in males, which explains the higher final weight in cocks compared with females.

The FCR was similar for the two varieties during the first 16 weeks and slightly lower in the golden black over the last 6 weeks.

\section{Carcass characteristics and meat quality}

Comparison between the two varieties of the Ardennaise breed of carcass characteristics and meat quality traits of animals slaughtered at 22 weeks of age revealed no significant difference. The results only showed that the weights of different body parts are higher in roosters compared with hens. Similar results were recorded by Youssao et al. (2009) in the Coqard chicken, which is a crossbred between traditional Ardennaises cock and hen from a French commercial slow growing strain. However, dressing percentage was better in the Ardennaise than in the French industrial red label, 67 and 65.5 percent, respectively.

After cooking, the average loss in the Ardennaise is about 20 percent which is considerably lower than the recommendations of Sauveur (1997) for the Label Rouge chicken (25 percent). However, the slaughter age of the latter is 12 weeks, while it is 22 weeks for the Ardennaise. The choice of this slaughter age ( 22 weeks) by the connoisseurs of Ardennaise, can be explained by the improved flavours and taste with age but at the expense of the tenderness (Touraille et al., 1981).

The ultimate $\mathrm{pH}$ of the muscles stabilizes to a value between 5.7 and 5.9 in poultry (Sante, Fernandez and
Monin, 2001). The values measured in the pectoral muscles of the two varieties of Ardennaises, around 5.7, are very close to this range and with the values found in different genetic groups by Debut et al. (2005) and Quentin et al. (2003) where ultimate $\mathrm{pH}$ ranged from 5.59 to 6.01 .

The colour, which represents the first criterion for assessing meat by the consumer and the absence of difference between the varieties of Ardennaise is interesting from the point of view of the uniformity of the commercial product. L* values recorded in the present study (48.3553.13) are lower than those recorded by Quentin et al. (2003) ranging from 54.5 in fast growing strains to 53.5 in slow growing strains including the French red label. The values of $\mathrm{a}^{*}$ of Ardennaises, 2.3-3.4, are higher than those recorded in many studies, ranging from -0.8 to 0.28 (Quentin et al., 2003; Debut et al., 2005). These high values of $\mathrm{a}^{*}$ indicate that the meat of Ardennaise is redder, in fact these values are closer to those recorded in turkeys ( $\mathrm{a}^{*}$ of about 5) in the study of Molette et al. (2005). The average value of $b^{*}$ (approximately 13) in the Ardennaise is much higher than those recorded (6.89-11.8) by Debut et al. (2005) and Quentin et al. (2003), therefore, a yellow colour is more pronounced in the Ardennaise.

\section{The laying rate and egg quality}

The hens of both varieties begin to lay at the age of 24 weeks, an age identical to that recorded by Hocking et al. (2003) on a group of traditional breeds (Barnvelder, White Sussex). However, this age remains well above that of industrial strains such as ISA-Brown (22 weeks of age) (Benabdeljelil et al., 2003). However, they are precocious compared with Indian breeds (Danki, Kalasthi and Ghagus) whose age at first egg varies from 25 to 32 weeks on average (Vij et al., 2006) and the Egyptian Fayoumi breed whose first egg is generally laid at the age of 28 weeks (Zaman, Sorensen and Howlider, 2004).

Even if there is no difference in the laying rate of the two varieties of Ardennaise, golden black hens lay more eggs than silver black hens (199 eggs vs 183 eggs). However, the weight of the latter is slightly higher (50.74 versus $49.53 \mathrm{~g}$ ). Similar differences were recorded in different varieties of the Gauloise (N'Dri, 2006).

The influence of age on the composition of the egg is already reported by numerous studies (Marion et al., 1964; Akbar et al., 1983; Fletcher et al., 1983; Nys, 1986; Rossi and Pompei, 1995; Hartmann et al., 2000; Dolgokorova, 2006).

The comparison of the two varieties of eggs had revealed some differences for certain traits at given age (Table 6).

The freshness of the egg is represented in this study by the $\mathrm{pH}$. Except at the age of 30 weeks where albumen $\mathrm{pH}$ was significantly higher in black golden Ardennaise (8.79 
versus 8.62 ), the $\mathrm{pH}$ of the white and the yellow were similar at the other ages. These values are comparable with those recorded by Moula et al. (2009a, 2009c).

The soundness of the shell is the second most important economic quality of the eggs (Wells, 1968). The fragility of the shell is the cause of about 6-8 percent of the losses in the egg industry (Washburn, 1982). In this study, the two Ardennaise varieties presented similar thicknesses at all ages (ranging from 30.65 to $33.08 \times 10^{-2} \mathrm{~mm}$ ), values close to those recorded by Moula et al. (2009c) in Ardennaise.

The third important criterion of the egg quality is the yellow-to-white ratio. High proportions of yellow are sought because it has a significant effect on the dry matter of the eggs (Harms and Hussein, 1993; Hartmann et al., 2003) which is an essential criterion in the industry (Flock, Preisinger and Schmutz, 2001). In this study, the Ardennaises golden black yellow/white ratio exceeds that of the silvery black Ardennaise (52.03-59.49 versus 49.72-56.38).

\section{Conclusion}

Most of the growth and laying traits as well as most of the quality characteristics of meat and egg did not differ significantly among the golden and silver varieties. These results might indicate that these varieties could be managed as one same population in order to face the problem of small population size.

It could be very interesting to complete this study by molecular markers analysis to evaluate the degree of genetic similarity between the two varieties. A wider study extended to the other ten varieties of Ardennaise would be welcome to fully assess the variability of the breed. This project should need the collaboration between public authorities, academic institutions and local race fans associations.

\section{Acknowledgements}

We are deeply grateful to Professor Antoine Clinquart (Department of Food Science, Faculty of Veterinary Medicine, ULg) and Professor Baudouin Nicks (Department of Animal Production, Faculty of Veterinary Medicine, ULg) who have generously put their laboratory equipment at our disposal. Special thanks to Pascal Nicolas, Aurélia Zizo, Guy Degand, Jacqueline Thimister and Abdellah Salhi for their support and collaboration.

\section{References}

Akbar, M.K., Gavora, J.S., Friars, G.W. \& Gower, R.S. 1983 Composition of eggs by commercial size categories effects of genetic group, age and diet. Poultry Scince, 62: 925-933.
Benabdeljelil, K., Lahbabi, S. \& Bordas, A. 2003. Comparison of crosses including a local breed or an experimental line to a commercial control for egg production in Morocco. Revue d'élevage et de médecine vétérinaire des pays tropicaux, 56: 193-198.

Carpiaux, E. 1921. Traité complet Aviculture. Edited by Imprimerie-Librairie J. Duculot: Gembloux, 344 p.

Debut, M., Berri, C., Baeza, E., Arnould, C., Guemene, D., Sante-Lhoutellier, V., Boutten, B., Jego, Y., Chapuis, H., Beaumont, C. \& Lebihan-Duval, E. 2005. Variabilité génétique de la qualité de la viande en relation avec les caractéristiques du muscle et la réponse au stress dans une lignée lourde de poulet. In Sixièmes Journées de la Recherche Avicole, Tours. St Malo.

Delgado, C., Rosegrant, M., Steinfeld, H., Ehui, S. \& Courbois, C. 1999. Livestock to 2020 the next food revolution. Discussion paper. A 2020 Vision for Food, Agriculture, and the Environment 28, International Food Policy Research Institute.

Dolgokorova, A.M. 2006. Morphology and biochemical composition of eggs in meat hens of different age. Russian Agricultural Sciences, 10: $21-24$.

FAO. 1981. Descripteurs des espèces avicoles. In: banque de données des ressources génétiques animales, Organisation des Nations Unies pour l'Alimentation et l'Agriculture: Rome, pp. 13-15.

Fletcher, D.L., Britton, W.M., Pesti, G.M. \& Rahn, A.P. 1983. The relationship of layer flock age and egg weight on egg component yields and solids content. Poultry Science, 62: 1800-1805.

Flock, D.K., Preisinger, R. \& Schmutz, M. 2001. Egg quality-a challenge for breeders of laying hens. In Proceedings of IX European Symposium on the Quality of Egg Products, Kusadasi, Turkey, pp. 55-61.

Harms, R.H. \& Hussein, S.M. 1993. The nutritional value of yolk: albumen ratio in hen eggs from commercial flocks. Journal of Applied Poultry Research, 2: 166-170

Hartmann, C., Johansson, K., Strandberg, E. \& Wilhemson, M. 2000. One-generation divergent selection on large and small yolk proportions in a White Leghorn Line. British Poultry Science, 41: 280286.

Hartmann, C., Johansson, K., Strandberg, E. \& Ryhmer, L. 2003. Genetic correlations between the maternal genetic effect on chick weight and the direct genetic effects on egg composition traits in a white leghorn line. Poultry Science, 82: 1-8.

Hocking, P.M., Bain, M., Channing, C.E., Fleming, R. \& Wilson, S. 2003. Genetic variation for egg production, egg quality and bone strength in selected and traditional breeds of laying fowl. British Poultry Science, 44: 365-373.

Lariviere, J.M. \& Leroy, P. 2005. Poultry Biodiversiy in Belgium. In 4th European Poultry Genetics Symposium, Dubrovnik, Croatia.

Lariviere, J.M. \& Leroy, P. 2008. Conservation et valorisation de la diversité des ressources génétiques du poulet en Europe : initiatives et perspectives. Annales de Médecine Vétérinaire, 152(4): 203-220.

Marion, A., Nordskog, A.W., Tolman, H.S. \& Forsythe, R.H. 1964. Egg composition as influenced by breeding, egg size, age and season. Poultry Science, 43: 255-264.

Molette, C., Serieye, V., Remignon, H. \& Babile, R. 2005 Comparaison des qualités sensorielles et technologiques de la viande de deux types génétiques de dindes. In : Sixièmes Journées de la Recherche Avicole, Tours. St Malo, 30 et 31 mars 2005.

Monira, K.N., Salahuddin, M. \& Miah, G. 2003. Effect of breed and holding period on egg quality characteristics of chicken. International Journal of Poultry Science, 2: 261-263. 
Moula, N., Antoine-Moussiaux, N., Farnir, F. \& Leroy, P. 2009a Evaluation of the production performances of an endangered local poultry breed, the Famennoise. International Journal of Poultry Science, 4: 389-396.

Moula, N., Antoine-Moussiaux, N., Farnir, F., Philippart, De Foy, M. \& Leroy, P. 2009b. Performances zootechniques de la poule Ardennaise, une race ancienne pour le futur? Annales de Médecine Vétérinaire, 153: 66-75.

Moula, N., Antoine-Moussiaux, N., Farnir, F. \& Leroy, P. 2009c. L'Ardennaise: statut de la race et de ses variétés. Annales de Médecine Vétérinaire, 153: 231-240.

Moula, N., Jacquet, M., Verelst, A., Antoine-Moussiaux, N., Farnir, F. \& Leroy, P. 2012. Les races de poules belges de grande taille. Annales de Médecine Vétérinaire, 156: 37-65.

N'Dri, A.L. 2006. Etude des interactions entre génotype et environnement chez le poulet de chair et la poule pondeus. (Thèse pour obtenir le grade de Docteur). Institut national agronomique : Paris-Grignon, 208 p.

Nys, Y. 1986. Relationship between age, shell quality and individual rate and duration of shell formation in domestic hens. British Poultry Science, 27: 253-259.

Parmar, S.N.S., Thakur, M.S., Tomar, S.S. \& Pilla, P.V.A. 2006. Evaluation of egg quality traits in indigenous Kadaknath breed of poultry. Livestock Research for Rural Development, 18, article 32.

Porter, T., Kebreab, E., Kuhi, H.D., Lopez, S., Strathe, A.B. \& France, J. 2010. Flexible alternatives to the Gompertz equation for describing growth with age in turkey hens. Poultry Science, 89: 371-378.

Quentin, M., Bouvarel, I., Berri, C., Le Bihan-Duval, E., Baeza, E., Jego, Y. \& Picard, M. 2003. Growth, carcass composition and meat quality reponse to dietary concentrations in fast-, medium- and slow-growing commercial broilers. Animal Research, 52: 65-77.

Rossi, M. \& Pompei, C. 1995. Changes in some egg components and analytical values due to hen age. Poultry Science, 74: 152-160.
Sante, V., Fernandez, X. \& Monin, G.I.P. 2001. Méthode de mesure de la qualité des viandes de volaille. INRA Production Animales, 14: 247-254.

SAS. 2001. SAS/STAT User's Guide. Version 9. SAS Inst. Inc., Cary, $\mathrm{NC}$.

Sauveur, B. 1997. Les critères et facteurs de la qualité des poulets Label Rouge. INRA Production Animales, 10: 219-226.

Touraille, C., Ricard, F.H., Kopp, J., Valin, C. \& Leclerq, B. 1981. Qualité du poulet. 2- évolution en fonction de l'âge des caractéristiques physico-chimiques et organoleptiques de la viande. Arch Geflugelk, 45: 97-104.

Tyler, C. \& Geake, F.H. 1964. Eggshell strength and its relationship to thickness, with particular reference to individuality in the domestic hen. British Poultry Science, 5: 3-18.

Vij, P.K., Tantia, M.S., Mishra, B., Bharani Kumar, S.T. \& Vijh, R. K. 2006. Characterization of Aseel, Danki, Kalasthi and Ghagus breeds of chicken. Indian Journal of Animal Science, 76: 944-949.

Voitellier, C. 1925. Aviculture, Les races de volailles, poules, Pintades, Dindons, Canards, Oies, Pigeons. Paris, Librairie J.-B Bailliére et Fils, Rue Hautefeuille, 19, Prés du Boulevard Saint Germain.

Washburn, K.W. 1982. Incidence, cause and prevention of egg shell breakage in commercial production. Poultry Science, 61: 2005-2012.

Wells, R.G. 1968. The measurement of certain egg quality charachteristics. In T.C. CARTER, ed. Egg Quality, A Study of the Hen's Egg. Edinburgh, OLIVIER \& BOYD, $331 \mathrm{pp}$

Youssao, A.K., Toleba, S.S., Dahouda, M., Adehan, R., Ahounou, G. S., Mama Ali, A.A., Gbangboche, A.B., Lariviere, J.M. \& Leroy, P. 2009. Growth performances and suitability for processing of Ardenne chicken in the sub-humid region of Benin. Livestock Research for Rural Development, 21: article 55.

Zaman, M.A., Sorensen, P. \& Howlider, M.A. 2004. Egg production performances of a breed and three crossbreeds under semi-scavenging system of management. Livestock Research for Rural Development, 16: article 8 . 